\title{
Review
}

\section{Diabetes mellitus due to viruses - some recent developments}

\author{
T.M.Szopa ${ }^{1}$, P.A. Titchener ${ }^{2}$, N. D.Portwood ${ }^{1}$, K. W. Taylor ${ }^{1}$ \\ ${ }^{1}$ Medical Unit, The Royal London Hospital, London, UK \\ ${ }^{2}$ Department of Microbiology, University of Reading, Reading, UK
}

Summary. Many different viruses belonging to several genera have the potential to damage beta cells. The mechanisms they employ are varied, and infection may result in either a direct destruction of islets and rapid insulin deficiency, or in a more gradual loss of functioning islets with the onset of diabetes many years later. Several case histories involving extensive cytolysis of beta cells can be directly linked to viral infection, whilst an example of diabetes occurring many years after viral infection is found in individuals who had a congenital infection with rubella virus. Here, the virus induces an autoimmune reaction against beta cells. Autoimmune phenomena have also been observed in islets following infections with viruses other than rubella, and thus activation of autoimmune mechanisms leading to beta-cell destruction may be a relatively frequent occurrence. Recent evidence shows that picornaviruses are not exclusively lytic, and can induce more subtle, long-term changes in beta cells, which may be important in the aetiology of diabetes. The exact mechanisms involved are not known, but it is clear that several viruses can directly inhibit insulin synthesis and induce the expression of other proteins such as interferons, and the HLA antigens. Strain differences in viruses are important since not all variants are tropic for the beta cells. Several laboratories are in the process of identifying the genetic determinants of tropism and diabetogenicity, especially amongst the Coxsackie $\mathrm{B}(\mathrm{CB})$ virus group. The sequence of one such diabetogenic CB4 strain virus has been determined. It is clear therefore that there are many viruses with the potential to induce diabetes, and a viral involvement in the pathogenesis of diabetes has been established in some instances. Further research work at both a fundamental and epidemiological level is now urgently needed to define the nature of the interaction of such viruses with the beta cell.

Key words: Beta cell, Coxsackievirus, diabetes, insulin-dependent diabetes mellitus, islet, picornavirus, virus.
Infections with many unrelated viruses have been associated with the development of diabetes mellitus, and almost one hundred years ago an observation that diabetes followed a recent infection with mumps virus was recorded [1]. In recent years a clearer relationship between a number of viral infections and the onset of diabetes has become better established, though a final picture of the relevance of viruses to diabetes and in particular to insulin-dependent diabetes, has yet to emerge. A review of recent developments with particular reference to the picornaviruses seems timely. This is especially so, since there appears to be a greatly renewed interest in the importance of environmental factors in the genesis of diabetes $[2,3]$. Viruses are the most likely of such factors to be involved in the development of insulindependent diabetes. This view is based on many serological and epidemiological studies [4-8] and case histories [9-11]. As shown in Table 1, the link between picornaviral infection and diabetes appears to be particularly strong and the two most notable case histories of viralinduced insulin-dependent diabetes involved members of the Coxsackie B (CB) group (Table 2). It has also been noted that the incidence of diabetes and glucose intolerance has increased following epidemics of picornavirus infection [12-14]. Moreover recent genetic studies detailing the sequence of some diabetogenic and pancreotropic strains of picornaviruses have been carried out [15-17].

There are two possible ways in which a virus could produce diabetes. The first is when overt disease develops after an interval of many years from the time of infection with virus. This is exemplified by diabetes in the congenital rubella syndrome (CRS) where infection takes place in utero and diabetes occurs 5-20 years later [18]. The second way appears to involve a direct assault on the pancreatic islets during the course of an acute viral infection. The full expression of diabetes resulting from a direct attack alone is probably a rare 
Table 1. Picornaviruses which have been implicated as causative agents of diabetes in humans and in animals

\begin{tabular}{|c|c|c|}
\hline Genus & Virus & Effect \\
\hline Aphthovirus & $\begin{array}{l}\text { Foot and mouth } \\
\text { disease virus }\end{array}$ & $\begin{array}{l}\text { Diabetogenic in } \\
\text { cattle [101] }\end{array}$ \\
\hline \multirow[t]{2}{*}{ Cardiovirus } & $\begin{array}{l}\text { Encephalomyo- } \\
\text { carditis virus } \\
\text { (myocardial strain) }\end{array}$ & $\begin{array}{l}\text { Diabetogenic in } \\
\text { mice [63] }\end{array}$ \\
\hline & $\begin{array}{l}\text { Mengovirus } \\
\text { (clone 2T) }\end{array}$ & $\begin{array}{l}\text { Diabetogenic in } \\
\text { mice [102] }\end{array}$ \\
\hline \multirow[t]{5}{*}{ Enterovirus } & Poliovirus & $\begin{array}{l}\text { Diabetes reported } \\
\text { in man following } \\
\text { infection [103] }\end{array}$ \\
\hline & $\begin{array}{l}\text { Coxsackievirus } \\
\text { (A group) }\end{array}$ & $\begin{array}{l}\text { Raised IgM levels in } \\
\text { diabetic patients [104] }\end{array}$ \\
\hline & $\begin{array}{l}\text { Coxsackievirus } \\
\text { (B group) } \\
\text { (several serotypes) }\end{array}$ & $\begin{array}{l}\text { Diabetogenic in hu- } \\
\text { mans and in mice }[10, \\
53,69], \text { in vitro effects } \\
\text { on beta cells }[66,67]\end{array}$ \\
\hline & $\begin{array}{l}\text { Echo virus } \\
\text { (4) }\end{array}$ & $\begin{array}{l}\text { Effects on human } \\
\text { and mouse } \\
\text { beta cells }[12,70]\end{array}$ \\
\hline & (2) & $\begin{array}{l}\text { Raised IgM levels in } \\
\text { diabetic patients [104] }\end{array}$ \\
\hline
\end{tabular}

Table 2. Case studies in which picornaviruses have been incriminated in the onset of diabetes in man

\begin{tabular}{|c|c|c|}
\hline Virus & Reference & Observations \\
\hline Untyped Coxsackie B & $\begin{array}{l}\text { Sussman et al. } \\
1959[105]\end{array}$ & $\begin{array}{l}\text { Islet degeneration, } \\
\text { no inflammation }\end{array}$ \\
\hline Coxsackie B1/B5 & $\begin{array}{l}\text { Nelson et al. } \\
1977[106]\end{array}$ & $\begin{array}{l}\text { Raised antibody titre, } \\
\text { Bornholm disease }\end{array}$ \\
\hline Coxsackie B1 & $\begin{array}{l}\text { Kaplan et al. } \\
1983 \text { [107] }\end{array}$ & $\begin{array}{l}\text { Infection in utero, } \\
\text { insulitis, virus in } \\
\text { pancreas }\end{array}$ \\
\hline Coxsackie B2 & $\begin{array}{l}\text { Wilson et al. } \\
1977 \text { [108] }\end{array}$ & Islet lymphocytosis \\
\hline Coxsackie B4 & $\begin{array}{l}\text { Gladisch et al. } \\
1976[9]\end{array}$ & $\begin{array}{l}\text { Insulitis, } \\
\text { viral antigen in islets }\end{array}$ \\
\hline Coxsackie B4 & $\begin{array}{l}\text { Yoon et al. } \\
1979[10]\end{array}$ & $\begin{array}{l}\text { Lymphocytic infil- } \\
\text { tration, virus isolated } \\
\text { from pancreas diabe- } \\
\text { togenic in mice }\end{array}$ \\
\hline Coxsackie B4 & $\begin{array}{l}\text { Asplin et al. } \\
1982 \text { [109] }\end{array}$ & Islet cell antibodies \\
\hline Coxsackie B4 & $\begin{array}{l}\text { Nihalani et al. } \\
1982[110]\end{array}$ & $\begin{array}{l}\text { Generalised Cox- } \\
\text { sackie B4 infection }\end{array}$ \\
\hline Coxsackie B5 & $\begin{array}{l}\text { Champsaur } \\
\text { et al. } 1980 \text { [11] }\end{array}$ & $\begin{array}{l}\text { Virus isolated from } \\
\text { stools produced glu- } \\
\text { cose intolerance in } \\
\text { mice }\end{array}$ \\
\hline Coxsackie B5 & $\begin{array}{l}\text { Ahmad and Abra- } \\
\text { ham } 1982 \text { [111] }\end{array}$ & $\begin{array}{l}\text { Mononuclear infil- } \\
\text { trate in islets }\end{array}$ \\
\hline Coxsackie B6 & $\begin{array}{l}\text { Nigro et al. } \\
1986[87]\end{array}$ & Islet cell antibodies \\
\hline
\end{tabular}

event. However, limited attacks by beta-cell tropic viruses leading to temporary hyperglycaemia or permanent subclinical damage to the islets may well occur. As is becoming evident this type of viral insult could easily be the triggering event for a complex series of immuno- logical changes which are associated with beta-cell destruction.

Apart from mumps and rubella virus, and some picornaviruses, there is recent evidence of possible associations of diabetes with cytomegalovirus (CMV) and retroviral infection. The majority of $\mathrm{CMV}$ infections, like rubella, are acquired congenitally and are initially subclinical. However, diabetes as a complication of CMV infection has been recorded [19]. One study has shown that about $15 \%$ of newly-diagnosed insulindependent patients have CMV-specific viral genome in their lymphocytes and islet cell antibodies (ICA) in their sera [20], indicating that autoimmune diabetes is sometimes associated with persistent CMV infection. Human CMV can also induce an ICA which reacts with the $38 \mathrm{kDa}$ autoantigen isolated from human pancreatic islets [21].

The possible importance of endogenous retroviruses in the development of diabetes has been brought to light by studies of the non-obese diabetic (NOD) mouse and the Biobreeding rat. In these models, the development of autoimmune diabetes appears to be conditional upon the presence of retroviruses. Clusters of retroviral particles (A type) have been found in beta cells of NOD mice in association with the insulitis preceding diabetes [22]. The exact role of retroviruses in the disease process is not clear, but specific expression of endogenous retrovirus by beta cell is linked to the development of insulitis and diabetes in these mice.

In addition in some mouse strains, treatment with streptozotocin induces aberrant retrovirus (C type) budding into the rough endoplasmic reticulum of beta cells before insulitis $[23,24]$. Intracisternal type A particles have also been observed in the necrotic beta cells of genetically diabetic mice [25].

\section{Picornaviruses and induction of diabetes}

Picornaviruses associated with either human or animal diabetes are shown in Table 1 . Of these only the $\mathrm{CB}$ viruses and possibly those of the echo group appear to be linked to the development of diabetes in man. Epidemiological and serological data which support this idea have been discussed in considerable detail elsewhere [26, 27]. Data on the appearance of Coxsackiespecific antibodies following diabetes are controversial, and difficulties are encountered with their interpretation. The majority of studies however, have found higher levels of viral antibodies in newly-diagnosed diabetic patients than in control subjects. Some studies have reported a lower viral antibody titre in diabetic children [28] indicating that there may be a reduction in immunological competence in individuals genetically susceptible to diabetes, or that exposure to virus in these individuals is less and results in a more severe disease later. Generally IgM levels are high during the early stages of an infection and their presence signifies an infection having occurred within the previous 8 weeks, which would suggest that an acute rather than persistent infection precedes the onset of diabetes. In one study, circulating 
IgA antibodies are present in individuals several years post-infection and a higher prevalence and mean titre of these CB antibodies have been found in diabetic children compared to control subjects [29], suggesting perhaps the establishment of a persistent infection.

The strongest evidence implicating members of the $\mathrm{CB}$ group as causative agents of insulin-dependent diabetes comes from the study of a number of case histories (Table 2). The most important of these involved CB4 and CB5 viruses $[10,11]$. In both instances virus was isolated from the patients ( $\mathrm{CB} 4$ specifically from the pancreas) and produced diabetes or glucose intolerance, respectively in susceptible mice. It is clear therefore, that in at least some instances the onset of diabetes is directly related to recent $\mathrm{CB}$ infection.

\section{Viral tropism}

The diversity of symptoms occurring in picornaviral infection are indicative of the fact that the picornaviruses are composed of many virions with distinct tropisms for specific tissues. Within a clinical isolate there are variants with different biological properties. The phenotypically stable diabetogenic encephalomyocarditis virus (EMC) contains a mixture of diabetogenic and non-diabetogenic virions [30]. $\mathrm{CB}$ viruses predominantly attack only the acinar tissue, but occasionally damaged islets have been observed [31, 32]. There are instances in which direct associations between $\mathrm{CB}$ viruses and diabetes exist, but since diabetes is only sometimes a sequel to outbreaks of $\mathrm{CB}$ virus infection, this indicates that only some variants of virus circulating in the natural population are tropic for the beta cells. Coleman et al. [33] used an unadapted CB4 isolate to infect mouse islets in vivo and in vitro and a transient hyperglycaemia developed in diabetes-susceptible mice. Other studies using clinical isolates similarly found that a proportion of mice develop hyperglycaemia or abnormal glucose indices $[34,35]$. Furthermore a significant number of random clinical isolates impaired islet function in vitro [36], and it is possible they could inflict subclinical damage in vivo, which in some individuals could contribute to the eventual decline and destruction of beta cells.

Tropism (the characteristics of a virus to infect a specific tissue or cell type) is thought to be regulated by attachment of virus to receptors. The expression of receptors is genetically determined and influenced by cell maturation and its functional state. As might be expected the passage of $\mathrm{CB}$ viruses through beta cells results in an increased tropism for these cells, by a selection of those viral variants that attach and preferentially replicate in them. This has been demonstrated in several studies [37, 38]. In EMC infection of diabetes-susceptible mice it has been found that viral titres are higher and the number of infected cells is greater than in non-susceptible mice due to a greater replication in the former. Similarly evidence exists for a greater replication of a mouse pancreas-adapted CB4 virus in murine islets compared to an unadapted CB4 virus (T. Szopa, unpublished data).

\section{Persistent infections, mutations, and islet tropic strains of virus}

Both host and virus selective pressures operate during an infection. The virus undergoes both phenotypic and genotypic changes, and these become particularly important during the course of a persistent infection. The picornaviruses were originally described as highly lytic viruses but it is now known that they can also establish persistent infections, and can cause damage by other means than a simple lysis. There is evidence for the persistence of poliovirus [39] and echo virus 9 and 30 in man [40]. The CB viruses have also been found to persist in man [41] and in mice $[42,43]$. In vitro several cell types e.g. lymphocytes, fibroblasts and pancreatic tumour cell lines can be infected in this manner by $\mathrm{CB}$ viruses [44-46] and also by echo 6 virus [47]. Particularly interesting are the reports of $\mathrm{CB}$ infection of human lymphoid cell lines and persistent CB4 infection of rat insulinoma cells in the absence of cytopathology [44-46]. A latent CB4 infection of a rat insulinoma cell line has been reported in which a change in cell function occurred with little change in morphology [48]. Significantly an acinar-tropic variant of CB4 has been found to persist in the pancreas of mice for several months post-infection [49] and it is possible than from this type of virus a highly beta-cell tropic variant could arise which would then attack the islets, some time after the initial infection.

There are two mechanisms by which RNA viruses can persist in cells - the steady-state or the carrier-culture system. In a steady-state infection all the cells are infected, whilst in the carrier culture only a proportion of cells is involved. The most likely mechanism thought to be used by the picornaviruses is the carrier-culture system, although a few members of the group e.g. echo 6 virus have been shown to establish steady-state infections [47].

Persistent infections are more readily established in infants whose immune system is immature e. g. rubella virus infection in utero which leads to autoimmune diabetes [50] by an as yet unknown mechanism. Similarly studies of CMV infection in utero have shown that there are islet cell antibodies (ICA) in newly-diagnosed diabetic patients and human-specific viral genome in lymphocytes [20,21]. Diabetes in this case could result from a response to expression of viral antigens or induction of beta-cell specific autoantigens.

The rate of mutation in picornaviruses is high [51] and accounts for the variety of clinical manifestations of infection. In CB4 virus the rate is estimated to be $10^{-4}$ mutations per base [52]. This high frequency means that diabetogenic variants could arise spontaneously in nature, or that during the course of either a subclinical infection or persistent infection a virus could at some time mutate into a strongly beta-cell tropic variant. Evidence that beta-cell tropic variants exist quite commonly in CB4 infection has been presented [36].

Long-term defects in islet function were found to occur in mice after infection with a mouse pancreas-adapted strain of CB4 virus 6 months earlier [53]. Although the islets of these mice were histologically normal and gross changes in blood glucose level were not found, insulin se- 
Table 3. Nucleotide differences between the prototype strain of coxsackie B4 virus (JVB) and the diabetogenic strain

\begin{tabular}{|c|c|c|c|c|c|}
\hline $\begin{array}{l}\text { Nucleotide } \\
\text { position }^{\text {a }}\end{array}$ & $\begin{array}{l}\text { CB4 } \\
\text { JVB }\end{array}$ & $\begin{array}{l}\text { P-CB4 } \\
\text { Diabetogenic }\end{array}$ & $\begin{array}{l}\text { Codon } \\
\text { change }\end{array}$ & $\begin{array}{l}\text { Amino acid } \\
\text { change }\end{array}$ & $\begin{array}{l}\text { Viral } \\
\text { protein }\end{array}$ \\
\hline 131 & $\mathbf{T}$ & $\mathrm{C}$ & & & \\
\hline 136 & $\mathrm{~T}$ & A & & & \\
\hline 137 & A & $\mathrm{G} / \mathrm{C}$ & & & \\
\hline 171 & $\mathrm{~T}$ & $\mathrm{C}$ & & & \\
\hline 546 & $\mathrm{G}$ & $\mathrm{C}$ & & & \\
\hline 572 & $\mathbf{T}$ & $\mathrm{C}$ & & & \\
\hline 750 & $\mathrm{G}$ & A & GCA-ACA & Ala-Thr & VP4 \\
\hline 812 & $\mathrm{G}$ & A & TCG-TCA & & \\
\hline 1112 & $\mathrm{C}$ & $\mathrm{T}$ & $\mathrm{ACC}-\mathrm{ACT}$ & & \\
\hline 1646 & $\mathrm{~T}$ & $\mathrm{C}$ & GTT-GTC & & \\
\hline 1787 & $\mathrm{~T}$ & $\mathrm{C}$ & GAT-GAC & & \\
\hline 2480 & $\mathrm{G}$ & A & ATG-ATA & Met-Ile & VP1 \\
\hline 3296 & $\mathrm{C}$ & $\mathrm{T}$ & CCC-CCT & & \\
\hline 4307 & $\mathrm{C}$ & $\mathrm{T}$ & TAC-TAT & & \\
\hline 4988 & $\mathrm{G}$ & A & $\mathrm{AGG}-\mathrm{AGA}$ & & \\
\hline 5015 & $\mathrm{G}$ & A & GCG-GAG & & \\
\hline 5086 & $\mathrm{~T}$ & $\mathrm{C}$ & GTA-GCA & Val-Ala & P3A \\
\hline 5124 & A & $\mathrm{G}$ & ATT-GTT & Ile-Val & P3A \\
\hline 5147 & $\mathrm{G}$ & $\mathrm{T}$ & AAG-AAT & Lys-Asn & $\mathrm{P} 3 \mathrm{~A}$ \\
\hline 5176 & $\mathrm{~T}$ & $\mathrm{C}$ & ATT-ACT & Ile-Thr & $\mathrm{P} 3 \mathrm{~A}$ \\
\hline 5405 & $\mathrm{~T}$ & $\mathrm{C}$ & AGT-AGC & & \\
\hline 5541 & $\mathrm{~T}$ & $\mathrm{C}$ & ТТА-СТА & & \\
\hline 5594 & $\mathrm{G}$ & A & CGG-CGA & & \\
\hline 6084 & $\mathrm{~T}$ & $\mathrm{C}$ & ТТC-CTC & Phe-Leu & P3D \\
\hline 6275 & A & $\mathrm{G}$ & TTA-TTG & & \\
\hline
\end{tabular}

a Jenkins et al. 1987 [57]

cretion and synthesis in the islets was impaired. How these changes induced by the virus persist is not known at the present time but the observations suggest that $C B$ viruses are capable of inducing subtle changes in islet cell metabolism which may be important in the pathogenesis of insulin-dependent diabetes.

Amongst other virus groups, a certain strain of lymphocytic choriomeningitis virus (LCMV) causes a persistent infection of beta cells in mice and induces changes in function without destruction of the cells [54]. This could occur by a reduction in the number of beta cells following infection, since the regenerative capacity of beta cells is poor, or alternatively a differentiated cell function (e.g. insulin production) could be turned off.

\section{The genetic basis of viral diabetogenicity}

The genetic basis of viral diabetogenicity can be investigated by comparative nucleotide sequence analysis of viral genomes. The complete nucleotide sequences of the diabetogenic EMC (D strain) and the non-diabetogenic EMC (B strain) have been established $[55,56]$ and it has been concluded that there are 14 nucleotide differences between the two strains. A second non-diabetogenic EMC variant has been sequenced in order to focus on the nucleotide changes responsible for the diabetogenic phenotype [15]. It appears that only two amino acids may be responsible for the diabetogenicity of EMC, one on the leader peptide and one on the coat protein VP1.

A similar approach has been used to examine the diabetogenic phenotype of CB4 virus. The complete nucleotide sequence of a mouse pancreas adapted variant of
CB4 has been determined [16] and compared to that of the previously published sequence of the non-diabetogenic prototype CB4 strain (JVB Benschoten) [57]. Twenty-five nucleotide sequence differences have been identified (Table 3). Of these differences, six occur in the 5' non-coding region of the genome and 19 in the coding region, resulting in seven amino acid changes. These comprise one in each of the coat proteins, (VP1 and VP4), one in the polymerase gene (P3D) and four in another non-structural protein $(\mathrm{P} 3 \mathrm{~A})$, for which a clear role has not yet been defined.

It can only be speculated upon at this time as to which of the nucleotide changes contribute to, or are responsible for, the diabetogenic phenotype in CB4, particularly as phenotypic changes may involve one or a few genomic alterations. Conversely, multiple mutations or deletions may be required. Whilst nucleotide changes were found in the coat proteins of the pancreas-adapted CB4 (in VP1 and VP4) and in the processing proteins (in P3A and $\mathrm{P} 3 \mathrm{D}$ ), it is the changes in the 5' non-coding region that are of most interest. The involvement of picornaviral 5' noncoding regions in viral replication has been and still is the subject of intense study. Alignment of enteroviral 5' noncoding region sequences highlights several stretches of conservation and pyrimidine rich regions with the potential to form stem and loop structures [58]. These common features suggest a functionally important role for the 5' non-coding region. Indeed for poliovirus some of the structural elements within this region have been shown to be necessary for efficient translation and replication of the viral genome [59-62]. The nucleotide changes identified in the genome of the beta-cell tropic CB4 5 ' non-coding region occur in the regions corresponding to those de- 
scribed for poliovirus. Whether the 5 ' non-coding region nucleotide changes act to alter the rate of viral replication alone, or in combination with nucleotide changes occurring elsewhere in the genome warrants further investigation.

\section{Metabolic effects of picornaviruses on islets}

\section{Studies in whole animals}

Extensive literature now exists on these effects. The earliest studies were with EMC virus where the myocardial variant induced very marked elevations of blood glucose in diabetes-susceptible mice [63]. In later studies CB4 and CB5 virus was isolated from patients dying in ketoacidosis and when injected into susceptible mice produced hyperglycaemia or glucose-intolerance respectively $[10,11]$.

In general however, the CB viruses are not strongly tropic for the beta cells and it is only in rare instances that a completely unadapted human $\mathrm{CB}$ isolate produces hyperglycaemia in mice [33]. This does not mean that more subtle changes might be induced in islets, as is explained later. Serial passage of CB1-CB6 through betacell cultures resulted in an increased tropism for beta cells and transient hyperglycaemia developed in mice following infection with them [38]. Similarly passage of CB4 through monkey cell cultures produced a virus capable of damaging islet function resulting in abnormal glucose tolerance [64]. The effects were enhanced by previous streptozotocin treatment indicating that viral infection may cause significant damage when acting upon a pancreas with a depleted cell reserve.

\section{Studies in isolated islets}

A number of studies show that picornaviruses may attack the islets directly causing impaired insulin synthesis and release $[65,66]$. In isolated mouse islets infected with a mouse pancreas-adapted CB4 preparation, over a 4-day period, insulin synthesis was reduced and insulin release at basal glucose concentration was increased [66]. Similar results were obtained when human islets were infected with a non-adapted CB4 preparation in vitro [67]. CB3 infection of human islets in culture also resulted in a decreased intracellular insulin content which appeared to parallel the increase in virus titre [68].

Mice infected with variants of CB4 tropic for beta cells show impaired function in islets for up to 6 months post infection [53]. Higher than normal amounts of insulin were released at non-stimulatory glucose concentration while glucose-stimulated insulin synthesis was inhibited. There was no evidence of changes in blood glucose in these animals or of histological damage to islets. Another group, using a CB4 variant plaque-purified from a myocardial isolate, found that beta cells from infected mice produced less insulin and that total protein synthesis was also reduced [69]. These changes related to alterations in blood glucose levels.
Similar experiments have been carried out in vitro and in vivo with mouse islets infected with a variant of echo 4 virus [70]. This variant was derived from an isolate obtained from an outbreak of echo 4 virus-induced meningoencephalitis among children in Cuba. It has also been reported that a significant number of these children developed glucose intolerance and ICA after infection [12].

\section{Mechanism of effects of diabetogenic viruses on protein synthesis in islets}

Much attention has been directed to the effects of viruses and particularly the picornaviruses on protein synthesis in islets. These viruses may affect insulin biosynthesis or the synthesis of other islet proteins such as the HLA antigens or the interferons. In several instances diabetogenic picornaviruses appear to be able to reduce insulin biosynthesis. This can sometimes take place without any concomitant destruction of beta cells and therefore it may be quite unrelated to cytolytic destruction as was first thought to be the case.

\section{Insulin biosynthesis}

It was shown in 1975 , that EMC virus reduced proinsulin synthesis in mouse islets [71]. The mechanism by which viruses reduce insulin synthesis is of great interest. With EMC virus the effect is biphasic. Insulin biosynthesis has been shown to be diminished as early as 2-h post infection in dispersed islets [72]. In whole islets there is no change in insulin secretion this early. In the second phase the virus produces a progressive loss of preproinsulin mRNA. This effect appears to be selective since mRNA for the constitutive protein glyceraldehyde 3-phosphate dehydrogenase was not reduced until long after infection. The early effects appear to be due to a "shut-off" of host protein synthesis as has been described for virus effects in other host tissues.

Some similar effects on insulin synthesis have been observed in mouse islets infected with a beta-cell tropic strain of CB4 [73, 74]. Again at an early phase of viral activity there is a selective inhibition of insulin synthesis.

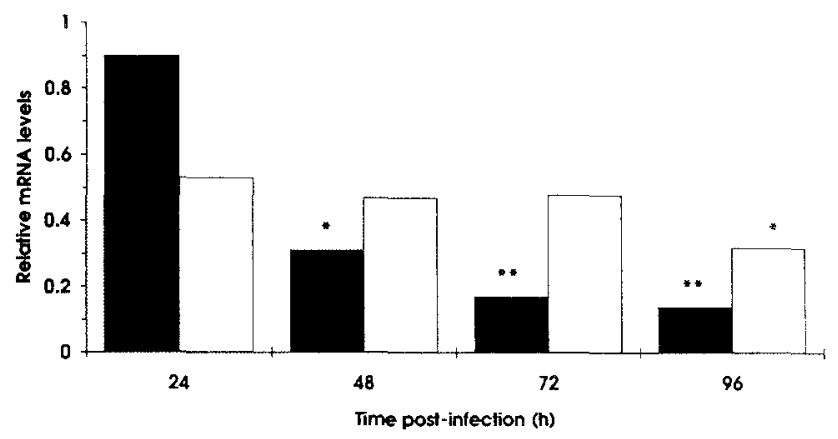

Fig. 1. Preproinsulin mRNA ( $\mathbf{a}$ ) and glyceraldehyde 3-phosphate dehydrogenase mRNA levels ( $\square$ ) in coxsackie B4 virus - infected mouse islets. Significant differences from the $24 \mathrm{~h}$ levels are denoted by $* p<0.002$ and $* * *<<0.001$ 
This is again accompanied by a rapid depression of preproinsulin mRNA (Fig. 1). It is not immediately clear why insulin synthesis should be preferentially inhibited in islets following both EMC and CB4 infection. However, the inhibition of host cell proteins seen with CB4 might be through the cleavage of the p 220 component of the initiation factor elF-4, as is the case with poliovirus [75]. At a later stage, if cytolysis takes place there will be a general and unregulated loss of islet cell protein synthesis.

\section{Picornaviruses and interferons}

As is well known the diabetogenic variants of EMC virus replicate to a high titre in the pancreas of mice and induce low levels of interferons, in contrast to the non-diabetogenic strains which replicate poorly and are high interferon inducers [30]. The interferon system seems therefore to be critically important in the development of diabetes following EMC infection.

It has also been shown that natural isolates of $\mathrm{CB} 4$ contain both interferon sensitive and non-sensitive variants of virus which modulate virulence [76]. However, it is much less certain whether or not interferons affect the response of beta cells to CB4 infection. The situation in islets is particularly complicated since interferons $\alpha$ and $\beta$ may impair insulin biosynthesis directly in vitro [77], and reduce (pro)insulin mRNA (N.D.Portwood, personal communication). These effects could be in response to an interferon-induced activation of endoribonuclease which would depress mRNA in islets. Alternatively interferons could induce an increased phosphorylation of the initiation factor elF-2, which would depress protein synthesis. Although EMC virus undoubtedly increases the production of interferons in islets, there is no evidence for similar increases in interferons in islets infected with CB4, as measured by immunoassay techniques (K. W. Taylor, personal communication). Moreover, CB4 variants, which attack islets do not affect the levels of the mRNA for the enzyme 2,5-A synthetase which is an indirect mediator of interferon activity. It appears therefore that interferons are much less important in altering islet function after CB4 infection than is the case with EMC virus.

\section{Induction of other proteins in islets by viruses}

Cytokines such as interferon, interleukins (IL) and tumour necrosis factor are released in increased amounts following virus infection and they alter the immune response by regulating the expression of beta-cell antigens and thus contribute to tissue inflammation.

In an earlier report reovirus was shown to cause a direct upregulation of HLA class I molecules in islets in vitro [78]. In human insulinoma cell lines measles and mumps virus induced the production of IL-1 and IL-6, and an increased expression of class I and class II antigens [79]. Moreover, a recent study showed that mumps, rubella and CB4 viruses enhanced class I expression in human fetal islets [80]. This is an important area in which further studies are needed.

\section{Autoimmunity and viruses}

Diabetes is considered by many to be a chronic autoimmune disease with exposure to an environmental factor being necessary to provoke the immunological reactions which lead to islet cell destruction. It is of importance to investigate which virus or viruses might provoke the immunological response leading to beta-cell destruction. Several antibodies have been associated with diabetes, many of them detectable some years before the onset of the disease e.g. ICA, islet cell surface antibodies (ICSA), insulin antibodies, and antibodies to the $64 \mathrm{kDa}$ antigen. In addition to the involvement of ICA in autoimmunity, there are known to be direct effects of ICA on beta cells; for example, ICSA are toxic to beta cells in the presence of complement [81] and ICA have been shown to alter insulin synthesis and release from islets in vitro $[82,83]$.

In man the clearest association between a viral infection and diabetes is that of diabetes in CRS and in congenital CMV infection. CRS is typical of an autoimmune disease by being associated with HLA-DR3 [84] and ICA [85] and occurring in $100 \%$ of genetically-susceptible individuals [86]. In CRS $12-20 \%$ of affected individuals develop diabetes 5-20 years post-infection [18]. In CMV infection ICA may be present which react with the $38 \mathrm{kDa}$ antigen in the pancreas [21]. ICA have also been detected in association with $\mathrm{CB}$ and echo 4 virus infection in man $[12,87]$. One report suggested that ICA occur with a higher frequency in those diabetic patients with moderate to high CB4 antibody titres [88]. With mumps infection the ICA induced are not always associated with diabetes [89].

Infection with a number of viruses, including picornaviruses, is associated with insulitis, one of the principle manifestations of diabetes. Monocytic infiltration is indicative of the ongoing autoimmune destruction of beta cells. This has been observed in a number of the case histories listed in Table 2 and in animal models of CB-induced diabetes. Similarly in studies of the pancreas of children dying from fulminant viral infections, insulitis was present in 4 of 5 of the cases attributable to CB viruses in one series [90] and in 4 of 7 cases in another [91].

In animal models, ICSA have been reported in EMCinfected mice prior to diabetes [92] and in mice infected with a variant of CB4 which causes metabolic changes in islets [83]. In addition antibodies against the $64 \mathrm{kDa}$ autoantigen, which is released with inflammatory damage, have also been detected in mice infected with a pancreatropic strain of CB4 [93]. The fact that ICA are not always detected when sought for, reflects perhaps the differences in the capacity of virus variants to induce antibodies.

The mechanisms by which a virus might initiate autoimmunity against beta cells is now the subject of considerable speculation. One possible mechanism by which viruses, and in particular the $\mathrm{CB}$ viruses, produce diabetes may be by molecular mimicry $[14,15]$. In molecular mimicry, sequence and epitope homologies between viral antigens and host determinants result in the generation of host-specific immune responses. A possible role for molecular mimicry in $\mathrm{CB}$-induced diabetes is sug- 
gested from studies of the $64 \mathrm{kDa}$ autoantigen released with inflammatory damage to the beta cells. This autoantigen has been identified as glutamic acid decarboxylase (GAD), the biosynthesizing enzyme of GABA, high levels of which are expressed in beta cells [96]. Kaufman et al. [97] and Bu et al. [98] noted that there was an extensive similarity between the $\mathrm{GAD}_{65}$ proteins and the P2C protein of CB4 virus. Human $G_{A D}$ contains a 24 amino acid residue which shares ten identities and nine similarities with the $\mathrm{P} 2 \mathrm{C}$ protein of $\mathrm{CB}$ viruses. Both these studies suggest that molecular mimicry may be involved in viral induction of insulin-dependent diabetes. Furthermore, a recent study has shown that $\mathrm{GAD}_{65}$ and Coxsackie B4 share 17 amino acid similarities and that there are two regions of sequence homology between $\mathrm{GAD}_{65}$ and human heat shock protein 65. An increased antibody reactivity to a CB4 nucleopeptide sharing with $\mathrm{GAD}_{65}$ an identical sequence of six amino acids has been found in the serum of insulin-dependent diabetic patients [99].

One model of virus infection triggering autoimmune diabetes in transgenic mice has been developed by Oldstone et al. [100]. LCMV glycoprotein or nucleoprotein was expressed in beta cells under the control of the rat beta-cell specific insulin II promotor gene. A subsequent challenge with LCMV provoked a lymphocytic infiltration restricted to the islets and later induced diabetes. This was explained by the fact that the beta cells expressing exogenous antigen only became a target for the immune system when viral infection provided signals to activate anti-beta-cell T-lymphocyte cytolysis. It is not known whether or not this takes place with other viruses.

Acknowledgements. We would like to thank Professor J. W. Almond and Dr. D. R. Gamble for helpful discussions. Much of the research work reported in this review has been funded by the British Diabetic Association and the Leverhulme Trust.

\section{References}

1. Harris HF (1899) A case of diabetes mellitus quickly following mumps. Boston Med Surg J 140: 465-469

2. Todd JA (1991) A protective role of the environment in the development of Type 1 diabetes. Diabetic Med 8: 906-910

3. Drash AL, Lipton RB, Dorman JS et al. (1991) The interface between epidemiology and molecular biology in the search for the causes of insulin-dependent diabetes mellitus. Ann Med 23: $463-471$

4. Gamble DR, Taylor KW (1969) Seasonal incidence of diabetes mellitus. BMJ 3: 631-633

5. Gamble DR, Kinsley ML, Fitzgerald MG, Bolton R, Taylor KW (1969) Viral antibodies in diabetes mellitus. BMJ 3: 627630

6. King ML, Shaikh A, Bidwell D, Voller A, Banatvala JE (1983) Coxsackie-virus-specific IgM responses in children with insulindependent diabetes mellitus. Lancet I: 1397-1399

7. Diabetes Epidemiology Research International (1987) Preventing insulin-dependent diabetes mellitus: the environmental challenge. BMJ 295: 479-481

8. Diabetes Epidemiology Research International (1990) Secular trends in the incidence of childhood IDDM in 10 countries. Diabetes 39: 858-864

9. Gladisch R, Hofmann W, Waldherr R (1976) Myocarditis and insulitis in Coxsackie virus infection. Z Kardiol 65: 873-881
10. Yoon J-W, Austin M, Onodera T, Notkins AL (1979) Virus-induced diabetes mellitus. Isolation of a virus from a child with diabetic ketoacidosis. New Engl J Med 300: 1173-1178

11. Champsaur H, Dussaix E, Samolyk D, Fabre M, Bach C, Assan R (1980) Diabetes and Coxsackie virus B5 infection. Lancet I: 251

12. Uriarte A, Cabrera E, Ventura R, Vargas J (1987) Islet cell antibodies and echo 4 virus infection. Diabetologia 30: A 590 (Abstract)

13. Wagenknecht LE, Roseman JM, Herman WH (1991) Increased incidence of insulin dependent diabetes mellitus following an epidemic of Coxsackie B5. Am J Epidemiol 133: 1024-1031

14. Rewers M, LaPorte RE, Walczak M, Dmochowski K, Bogaczynska E (1987) Apparent epidemic of insulin-dependent diabetes mellitus in Midwestern Poland. Diabetes 36: 106-113

15. Bae Y-S, Eun H-M, Pon RT, Giron GW, Yoon J-W (1990) Two amino acids, Phe-16 and Ala-776, on the polyprotein are most likely to be responsible for the diabetogenicity of EMC virus. J Gen Virol 71: 639-645

16. Titchener PA (1991) Genetic studies on coxsackievirus B4 tissue tropism. Ph.D Thesis, University of Reading, Reading, UK

17. Ramsingh A, Araki H, Bryant S, Hixson A (1992) Identification of candidate sequences that determine virulence in Coxsackie B4. Virus Res 23: 281-292

18. Menser MA, Forrest JM, Bransby RD (1978) Rubella infection and diabetes mellitus. Lancet I: 57-60

19. Ward KP, Galloway WH, Auchterlonie IA (1979) Congenital cytomegalovirus and diabetes. Lancet I: 497

20. Pak C-Y, McArthur RG, Eun H-M, Yoon J-W (1988) Cytomegalovirus infection with autoimmune type I diabetes. Lancet I: $1-14$

21. Pak CY, Cha CY, Rajotte RV, McArthur RG, Yoon J-W (1990) Human pancreatic islet cell specific $38 \mathrm{kD}$ autoantigen identified by cytomegalovirus-induced monoclonal islet cell autoantibody. Diabetologia 33: 569-572

22. Suenaga K, Yoon J-W (1988) Association of beta cell specific expression of endogenous retrovirus with the development of insulitis and diabetes in NOD mice. Diabetes 37:1719-1726

23. Like AA, Chick WL (1970) Studies on the diabetic mutant mouse. II. Electron microscopy of pancreatic islets. Diabetologia $6: 216-242$

24. Like AA, Rossini AA (1976) Streptozotocin-induced pancreatic insulitis: a new model of diabetes mellitus. Science 193: 415417

25. Leiter EH, Bedigian HG (1979) Intracisternal type A particles in genetically diabetic mice: identification in pancreas and induction in cultured B-cells. Diabetologia 17: 175-185

26. Gamble DR (1980) The epidemiology of insulin-dependent diabetes with particular reference to the relationship of virus infection to its etiology. Epidemiol Rev 2: 49-70

27. Barrett-Connor E (1985) Is insulin-dependent diabetes mellitus caused by coxsackievirus B infection? A review of epidemiologic evidence. Rev Infect Dis 7:207-215

28. Palmer JP, Cooney MK, Ward RH et al. (1982) Reduced coxsackie antibody titres in type 1 (insulin-dependent) diabetic patients during an outbreak of Coxsackie B3 and B4 infection. Diabetologia 22: 426-429

29. Hyoty H, Huupponen T, Kotola L, Leinikki P (1986) Humoral immunity against viral antigens in type I diabetes: altered IgA class immune response against Coxsackie B4 virus. Acta Path Microbiol Immunol Scand 94: 83-88

30. Yoon J-W, McClintock PR, Onodera T, Notkins AL (1980) Virus induced diabetes mellitus. XVIII. Inhibition by a nondiabetogenic variant of encephalomyocarditis virus. J Exp Med 152: 878-892

31. Burch GE, Tsui C-Y, Harb JM, Colcolough HL (1971) Pathologic findings in the pancreas of mice infected with coxsackievirus B4. Arch Intern Med 128: 40-47

32. Tsui C-Y, Burch GE, Harb JM (1972) Pancreatitis in mice infected with coxsackievirus B. Arch Path 93:379-389 
33. Coleman TJ, Taylor KW, Gamble DR (1974) The development of diabetes following Coxsackie B virus infection in mice. Diabetologia 10: 753-759

34. Kuno S, Itagaki A, Yamazaki I, Katsumoto T, Kurimura T (1984) Pathogenicity of newly isolated Coxsackievirus B4 for mouse pancreas. Acta Virol 28: 433-436

35. Jordan GW, Bolton V, Schmidt N (1985) Diabetogenic potential of Coxsackie B viruses in nature. Arch Virol 86: 213-221

36. Szopa TM, Ward T, Dronfield DM, Portwood ND, Taylor KW (1990) Coxsackie B4 viruses with the potential to damage beta cells of the islets are present in clinical isolates. Diabetologia 33: 325-328

37. Yoon J-W, Onodera T, Notkins AL (1978) Virus-induced diabetes mellitus: beta cell damage and insulin-dependent hyperglycaemia in mice infected with coxsackievirus B4. J Exp Med 148: 1068-1080

38. Toniolo A, Onodera T, Jordan G, Yoon J-W, Notkins AL (1982) Virus-induced diabetes mellitus: glucose abnormalities produced in mice by the six members of the Coxsackie B virus group. Diabetologia 31: 496-499

39. Wyatt HV (1973) Poliomyelitis in hypogammaglobulinemics. $J$ Infect Dis 128: 802-806

40. Wilfert CM, Buckley RH, Mohanakamur Tet al. (1977) Persistent and fatal nervous system echo virus infection in patients with agammaglobulinemia. New Eng J Med 296: 1485-1489

41. Bowles NE, Richardson PJ, Olsen EGJ, Archard LC (1986) Detection of Coxsackie-B-virus-specific RNA sequences in myocardial biopsy samples from patients with myocarditis and dilated cardiomyopathy. Lancet I: 1120-1123

42. Schnurr DP, Cao Y, Schmidt NJ (1984) Coxsackie B3 virus persistence and myocarditis in $\mathrm{N}: \mathrm{NIH}(\mathrm{s})$ II nu/nu and $+/$ nu mice. $\mathrm{J}$ Gen Virol 65: 1197-1201

43. Bocharov EV, Shalaurova BV (1984) Persistence of Coxsackie $\mathrm{B} 1$ virus in $\mathrm{BALB} / \mathrm{c}$ mice. Acta Virol 28: 345

44. Matteuci D, Paglianti M, Giangregorio AM, Capobianchi MR, Dianzani F, Bendinelli M (1985) Group B Coxsackieviruses readily establish persistent infections in human lymphoid cell lines. J Virol 56: 651-654

45. Schnurr DP, Schmidt NJ (1984) Persistent infection of mouse fibroblasts with coxsackievirus. Arch Virol 81: 91-101

46. Frank JA Jr, Schmidt EV, Smith RE, Wilfert CM (1986) Persistent infections of rat insulinoma cells with Coxsackie B4 virus. Arch Virol 87: 143-150

47. Gibson JP, Righthand F (1985) Persistence of echovirus 6 in cloned human cell lines. J Virol 54: 219-223

48. Montgomery L, Gordon D, George K, Maratos-Flier E (1991) Coxsackie infection of insulinoma cells leads to viral latency and altered insulin and class I MHC expression. Diabetes 40: $150 \mathrm{~A}$. (Abstract)

49. Vella C (1990) Coxsackie B4 infection of the pancreas - a murine model. Ph.D Thesis, University of London, London, UK

50. Rabinowe SL, George KL, Laughlin R, Soeldner JS, Eisenbarth GS (1986) Congenital rubella: monoclonal antibody defined T-cell abnormalities in young children. Am J Med 81: $779-782$

51. Holland J, Spindler K, Horodyski F, Grabau B, Nichol S, Vandepol S (1987) Rapid evolution of RNA genomes. Science 215: $1577-1585$

52. Prabhakar BJ, Haspel MV, McClintock PR, Notkins AL (1985) Detection of conserved and nonconserved epitopes on Coxsackie virus B: frequency of antigenic change. Virology 146 : 302-306

53. Szopa TM, Dronfield DM, Ward T, Taylor KW (1989) In vivo infection of mice with Coxsackie B4 virus induces long-term functional changes in pancreatic islets with minimal alteration in blood glucose. Diabetic Med 6:314-319

54. Oldstone MBA, Southern P, Rodriguez M, Lampeter P (1984) Virus persists in the beta cells of islets of Langerhans and is associated with chemical manifestations of diabetes. Science 224: $1440-1443$
55. Cohen SR, Naviaux RK, Vanden Brinck KM, Jordan GW (1988) Comparison of the nucleotide sequences of diabetogenic and nondiabetogenic encephalomyocarditis virus. Virology 166: 603-607

56. Bae Y-S, Eun H-M, Yoon J-W (1989) Genomic differences between the diabetogenic and nondiabetogenic variants of encephalomyocarditis virus. Virology 170:282-287

57. Jenkins O, Booth JD, Minor PD, Almond JW (1987) The complete nucleotide sequence of Coxsackie virus B4 and its comparison to other members of the Picornaviridae. J Gen Virol 68: $1835-1848$

58. Rivera VM, Welsh JD, Maizel JV (1988) Comparitive sequence analysis of the 5' noncoding region of enteroviruses and rhinoviruses. Virology 165: 42-50

59. Pelletier J, Sonenberg N (1988) Internal initiation of translation of eukaryotic mRNA directed by a sequence derived from poliovirus RNA. Nature 334: 320-325

60. Pelletier J, Sonenberg N (1989) Internal binding of eukaryotic ribosomes on poliovirus $m$ RNA: translation in HeLa cell extracts. J Virol 63: 441-444

61. Trono D, Andino R, Baltimore D (1988) An RNA sequence of hundreds of nucleotides at the 5' end of poliovirus RNA is involved in allowing viral protein synthesis. J Virol 62: 2291-2299

62. Trono D, Pelletier J, Sonenberg N, Baltimore D (1988) Transla tion in mammalian cells of a gene linked to the poliovirus 5 ' noncoding region. Science $241: 445-448$

63. Craighead JE, McLane MF (1968) Diabetes mellitus: induction in mice by encephalomyocarditis virus. Science 162: 913-914

64. Yoon J-W, London WT, Curfman BL, Brown RL, Notkins AL (1986) Coxsackievirus B4 produces transient diabetes in nonhuman primates. Diabetes 35:712-716

65. Hellqvist LNB, Taylor KW, Zaluzny S (1981) Selective disorganisation of biochemical function in B cells of islets of Langerhans infected by EMC-M virus in tissue culture. FEBS Lett 132: 215-218

66. Szopa TM, Gamble DR, Taylor KW (1986) Coxsackie B4 virus induces short-term changes in the metabolic functions of mouse pancreatic islets in vitro. Cell Biochem Funct 4: 181-189

67. Szopa TM, Ward T, Taylor KW (1986) Impaired metabolic func tion in human pancreatic islets following infection with Coxsackie B4 virus in vitro. Diabetologia 30: 587 (Abstract)

68. Yoon J-W, Onodera T, Notkins AL (1978) Virus-induced diabetes mellitus. XI. Replication of Coxsackie virus B3 in human pancreatic beta cell culture. Diabetes 27: 778-781

69. Chatterjee NK, Haley TM, Nejman C (1986) Functional alterations in pancreatic $\beta$ cells as a factor in virus-induced hyperglycaemia. J Biol Chem 260: 12786-12791

70. Szopa TM, Ward T, Taylor KW (1992) Disturbance of mouse pancreatic $\beta$-cell function following echo 4 virus infection. Biochem Soc Trans 20: 3155

71. Petersen K-G, Heilmeyer P, Kerp L (1975) Synthesis of proinsulin and large glucagon immunoreactivity in isolated islets of Langerhans from EMC virus infected mice. Diabetologia 11: $21-25$

72. Ward T, Clemens J, Taylor KW (1990) Effects of a diabetogenic strain of encephalomyocarditis virus on protein synthesis in mouse islets of Langerhans. Biochem J 270:777-781

73. Portwood ND, Taylor KW (1990) Coxsackie B4 virus-induced changes in mouse pancreatic $\beta$-cell mRNAs. Biochem Soc Trans 18: 1264

74. Portwood ND, Clemens MJ, Taylor KW (1991) Differential effects of Coxsackie B4 virus on murine pancreatic preproinsulin mRNA. Biochem Soc Trans 19:398

75. Krausslich HG, Niclin MHJ, Toyoda H, Etchison D, Wimmer E (1987) Poliovirus proteinase $2 \mathrm{~A}$ induces cleavage of eucaryotic initiation factor 4F polypeptide p220. J Virol 61:2711-2718

76. Jordan GW, Bolton V (1986) Interferon-sensitive coxsackievirus variants in nature. J Interf Res 5:289-296

77. Rhodes CJ, Taylor KW (1985) Effect of interferon and doublestranded RNA on B-cell function in mouse islets of Langerhans. Biochem J 228: 87-94 
78. Campbell IL, Harrison LC, Ashcroft RG, Jack I (1988) Reovirus infection enhances expression of class I proteins on human B-cells and rat RIN m5B cells. Diabetes 37: 362-365

79. Cavallo MG, Baroni MG, Toto A et al. (1992) Viral infection induces cytokine release by islet beta cells. Immunology 75:664668

80. Parkkonen P, Hyoty H, Koskinen L, Leinikki P (1992) Mumps virus infects beta cells in human fetal islet cell cultures upregulating the expression of HLA class I molecules. Diabetologia 35: 63-69

81. Dobersen MJ, Scharf JE, Ginsberg-Fellner F, Notkins AL (1980) Cytotoxic autoantibodies to $\beta$-cells in the serum of patients with insulin dependent diabetes mellitus. New Engl J Med 303: 1493-1498

82. Kanatsuna T, Lernmark A, Rubenstein AH, Steiner DF (1981) Block in insulin release from column perifused pancreatic $\beta$ cells induced by islet cell surface antibodies and complement. Diabetes 30: 231-234

83. Dronfield DM (1992) Viruses, islet cell antibodies, and pancreatic B-cell function. Ph. D Thesis, University of London, London, UK

84. Rubinstein P, Walker ME, Fedun B, Witt ME, Cooper LZ, Ginsberg-Fellner F (1982) The HLA system in congenital rubella patients with and without diabetes. Diabetes 31: 1088 1091

85. Ginsberg-Fellner F, Witt ME, Yagihashi S et al. (1984) Congenital rubella syndrome as a model for type 1 (insulin-dependent) diabetes mellitus: increased prevalence of islet cell surface antibodies. Diabetologia 27:87-89

86. Drash AL, Lipton RB, Dorman JS et al. (1991) The interface between epidemiology and molecular biology in the search for causes of insulin-dependent diabetes mellitus. Ann Med 23: $463-471$

87. Nigro G, Pacella ME, Patane E, Midulla M(1986) Multi-system Coxsackie B-6 infection with findings suggestive of diabetes mellitus, Eur J Paediatr 145: 557-559

88. Schemthaner G, Ludwig H, Mayr WR (1978) Coxsackie B4 viral infection, anti-islet immunity and immunogenetics in insulin-dependent diabetes mellitus. Acta Diabet Lat 15: 184-191

89. Scherbaum WA, Hampl W, Muir P et al. (1991) No association between islet cell antibodies and Coxsackie B, mumps, rubella and cytomegalovirus antibodies in non-diabetic individuals aged 7-19 years. Diabetologia 34: 835-838

90. Ujevich MM, Jaffe R (1980) Pancreatic islet cell damage in children with fatal viral infections. Arch Path Lab Med 104: $438-441$

91. Jenson AB, Rosenberg HS, Notkins AL (1980) Pancreatic damage in children with fatal viral infections. Lancet II: $354-358$

92. Buschard K, Rygaard J, Ropke C, Lund E (1986) Circulating islet cell antibodies in virus induced diabetes antecede clinical disease. Diabetes 35: 185 (Abstract)

93. Gerling I, Chatterjee NK, Nejman C (1991) Coxsackie B4-induced development of antibodies to $64,000-\mathrm{M}_{\mathrm{r}}$ islet autoantigen and hyperglycaemia in mice. Autoimmunity 10:49-56

94. Notkins AL (1984) On the track of viruses. Nature 311:209-210

95. Oldstone MBA (1987) Molecular mimicry and autoimmune disease. Cell 50:819-820

96. Baekkeskov S, Aanstoot H-J, Christgau S et al. (1990) Identification of the $64,000 \mathrm{~K}$ autoantigen in insulin dependent diabetes as the GABA synthesizing enzyme glutamic acid decarboxylase. Nature 347: 151-153

97. Kaufman DL, Erlander MG, Clare-Salzler M, Atkinson MA, Maclaren MA, Tobin AJ (1992) Autoimmunity to two forms of glutamate decarboxylase in insulin-dependent diabetes mellitus. J Clin Invest 89: 283-292

98. Bu D-F, Erlander MG, Hitz BC et al. (1992) Two human glutamate decarboxylases 65-kDa GAD and 67-kDa GAD, are encoded by a single gene. Proc Natl Acad Sci USA 89: 2115-2119

99. Jones DB, McLaughlin PJ, Armstrong N, Yeung M, Coulson A (1992) Does Coxsackie B4 virus infection induce GAD and HSP65 autoreactivity in type 1 diabetes? Diabetic Med 9 [Suppl 2]: 524 (Abstract)

100. Oldstone MBA, Nerenberg M, Southern P, Price J, Lewicki H (1991) Virus infection triggers insulin-dependent diabetes mellitus in a transgenic model; role of anti-self (virus) immune response. Cell 65: 319-331

101. Barboni E, Mannochio I, Asdurbali G (1966) Observations on diabetes mellitus associated with experimental foot and mouth disease in cattle. Vet Ital 17:362-368

102. Yoon J-W, Morishima T, McClintock PR, Austin M, Notkins AL (1984) Virus-induced diabetes mellitus: mengovirus infects pancreatic beta cells in strains of mice resistant to the diabetogenic effects of encephalomyocarditis virus. J Virol 50: 684690

103. John HJ (1934) The diabetic child. Etiologic factors. Ann Intern Med 8: 198-213

104. Frisk G, Nilsson E, Tuvemo T, Friman G, Diderholm H (1992) The possible role of coxsackie $A$ and echo virus in the pathogenesis of type 1 diabetes mellitus studied by $\operatorname{IgM}$ analysis. J Infect 24: $13-22$

105. Sussman ML, Strauss L, Hodes HL (1959) Fatal Coxsackie group B virus infection in the newborn. Am J Dis Child 97: 483 492

106. Nelson PG, Arthur LJH, Gurling KJ, Gamble DR, Taylor KW (1977) Familial juvenile-onset diabetes. BMJ 2: 1126-1127

107. Kaplan MH, Klein SW, McPhee J, Harper RG (1983) Coxsackie virus infections in infants younger than 3 months of age: a serious childhood illness. Rev Infect Dis 5: 1019-1032

108. Wilson C, Connolly JM, Thomson D (1977) Coxsackie B2 virus infection and acute onset diabetes in a child. BMJ 1: 1008

109. Asplin CM, Cooney MK, Crossley JR, Dornan TL, Raghu P, Palmer JP (1982) Coxsackie B4 infection and islet cell antibodies three years before overt diabetes. J Pediatr 101: 398-400

110. Nihalani KD, Pethani RR, Menon PS, Mehtalia SD (1982) Coxsackie $\mathrm{B}_{4}$ virus causing insulin dependent diabetes mellitus, myopericarditis and encephalitis - a case report. JAPI 30: 107109

111. Ahmad N, Abraham AA (1982) Pancreatic isleitis with Coxsackie virus B5 infection. Hum Path 13: 661-662

Prof. K. W. Taylor

Medical Unit

Royal London Hospital

Whitechapel

London E1 1BB

UK 